\title{
Use of Egress Modelling in Performance-Based Fire Engineering Design-A Fire Safety Study at the National Gallery of Victoria
}

\author{
PETER F. JOHNSON
}

Scientific Services Laboratory

177 Salmon Street

Port Melbourne VIC 3207

Australia

VAUGHAN R. BECK and MAHMUT HORASAN

Victoria University of Technology

Ballarat Road

Footscray VIC 3011

Australia

\begin{abstract}
Fire research has provided engineers with practical models and data that can be used to undertake performance based fire engineering analysis. This form of analysis is demonstrated in the development of a fire safety design strategy for the National Gallery of Victoria which required a significant upgrade of fire safety measures.
\end{abstract}

As part of the development of the fire safety strategy, the analysis undertaken required input on evacuation times as part of an egress study. A full evacuation of the Gallery provided valuable data to compare with EVACNET+ model predictions.

Experimental evacuation data and observations of human behaviour were consistent with other research in this field and highlighted a number of issues that fire safety designers and regulators need to take into account in the design and operation of buildings. In particular, the evacuation raised serious issues about the use of fire rated stairs in public buildings.

KEYWORDS: Art gallery, fire engineering, egress, evacuation models, human behaviour, exits, stairs, public buildings. 


\section{INTRODUCTION}

The National Gallery of Victoria (NGV) is one of Australia's largest art museums housing Victoria's major collection of artwork and significant exhibitions. The construction of the Gallery was completed in 1968 and it is a key building in Melbourne's art precinct just south of the city centre.

The replacement value of the Gallery building is estimated at A\$150 million in 1993 figures. Furthermore the Gallery's collection has been estimated at several billion dollars.

Given the value of the Gallery and its artworks and the need to protect the public and staff that may number up to 3000 at any one time, the NGV management commissioned the authors to undertake a performance based fire engineering study. The purpose of the study was to develop at package of new fire safety measures to bring the level of occupant safety and protection of the Gallery building and its contents up to modern levels.

In the study, an analysis of occupant safety adopted the concept of Available Safe Egress Time (ASET) developed by Cooper[1]. A hazard analysis and fire models were first used to develop the time to onset of life threatening conditions in major egress routes for a range of expected fire scenarios. These times were then compared to the times for complete evacuation of the building using the fire model EVACNET+[2] and the relationships developed by Pauls[3].

In making use of the egress model EVACNET+ for the maximum Gallery population, some confidence was needed that the model would yield reliable predictions. The authors decided that, with the agreement of NGV management, a full evacuation would be undertaken on a Sunday afternoon when the Gallery was usually heavily populated to provide observational data to compare with the EVACNET+ predictions.

Such opportunities to undertake a full building evacuation of unsuspecting occupants in a public assembly building are somewhat rare. This paper, while providing some detail of the broader fire engineering study, concentrates on the evacuation aspects and compares observed data with information from modelling and theory that we believe will advance research in this field.

\section{THE GALLERY AND EXISTING FIRE SAFETY MEASURES}

The National Gallery of Victoria has undergone little change since initial construction in 1968. It is a large impressive building of some $45,000 \mathrm{~m} 2$ in total floor area, sitting on a base of some $9000 \mathrm{~m} 2$. The NGV is spread over 4 main gallery floors plus an occupied roof space and two basement levels that are mainly carparks. Three internal courtyards, each approximately $800 \mathrm{~m} 2$, are located along the north-south centreline of the building. Two are open to the sky and the third has now been roofed over and serves as an atrium.

The major construction elements are masonry walls and concrete slab floors. However, around the perimeter of the building the internal wall lining and many of the internal walls and partitions are made of a combustible plywood. 
There is no effective fire compartmentation of the four Gallery levels above grade due to

(a) floors being connected by open stairs, escalators and the entrance foyers

(b) the first and third floors having large sections that are effectively open mezzanines of the ground and the second floors retrospectively, and

(c) all floors being joined by the roofed over courtyard atrium.

In addition to the large open public gallery spaces, there are a range of smaller areas for storage of artworks and offices, conservation, display/printing and workshops.

The basements and some of the conservation areas on the ground floor are sprinkler protected but the remainder of the Gallery and workspaces have no sprinkler protection. There is a thermal (heat) and limited smoke detection system but it is now 30 years old. A public address system is used for alarms that is operated from a main building control centre and there are exit signs. There are hydrants and portable extinguishers but no smoke management system.

In general terms, it is expected that if a fire were to occur in the Gallery, particularly in the smaller office, storage or work room areas, and if the fire was not extinguished by staff at an early stage, then this fire would have the potential to grow and spread throughout the Gallery. The rate of possible fire growth and spread is a reflection of the:

combustible nature of the works of art extensive use of plywood timber partitioning and lining use of corridors for storage of artworks lack of compartmentation in the building lack of an automatic suppression system

This scenario is supported by large, highly destructive fires in unsprinklered art galleries and other collecting institutions such as libraries and museums that include the following:

\author{
Museum of Modern Art, Rio de Janerio[4] \\ Los Angeles Central Library[5]
}

San Diego Aerospace Museum and Library[4]

\title{
GENERAL STUDY METHODOLOGY
}

Before dealing with the detail of the evacuation study, an outline is given of the fire safety engineering approach adopted for the building which is comprehensively documented in the full engineering study report[6]. The methodology chosen was that commonly called the deterministic approach in which the times of key fire events are identified for one or more design fires or fire scenarios. This approach has been used in Australia[7] to examine the performance of a range of fire safety measures such as smoke detectors, automatic sprinklers, new egress measures etc.. 
In respect of life safety, the analysis examines the time to untenable conditions in egress paths and compares this with the times for evacuation to see if additional fire safety measures can increase the margin of safety for building occupants making their escape under fire conditions. This approach is the one developed by Cooper[1] and for the NGV project the following equations were defined

$\begin{array}{llll}\begin{array}{l}\text { 1. Evacuation }= \\ \text { Time Required }\end{array} & \begin{array}{l}\text { Time for last } \\ \text { person to reach } \\ \text { safety commenced egress }\end{array} & \begin{array}{l}\text { Time at which } \\ \text { first person }\end{array} \\ \text { ED }(\text { REQ })= & \text { T }(E G L) & - & \text { T (EGF) }\end{array}$

2. Evacuation $=$ Time at which $\quad-\quad$ Time at which

$\begin{array}{lll}\text { Duration } & \text { Lethal conditions } & \text { First person } \\ \text { Available } & \text { are created } & \text { commenced egress }\end{array}$

$\mathrm{ED}(\mathrm{AVA}) \quad=\quad \mathrm{T}(\mathrm{LET}) \quad-\mathrm{T}(\mathrm{EGF})$

Using this approach, the fire safety design criterion was defined to be:

$\begin{array}{lc}\text { Evacuation Duration }< & \text { Evacuation Duration } \\ \text { Required } & \text { Available }\end{array}$

$\mathrm{ED}(\mathrm{REQ})<\quad \mathrm{ED}(\mathrm{AVA})$

This is a simplified approach in many respects; for example, no account is taken of durations required for human decision making, investigation and action by occupants prior to deciding to undertake egress behaviour. However with trained Gallery staff responding to coded alarms, these times were expected to be quite short.

To take the term ED (AVA) first, the time between when the first person responds to an alarm, $T$ (EGF), and the time to lethal conditions, $T$ (LET), is strongly dependent on the rate of fire growth.

In order to define expected fire scenarios and maximum growth rates, a survey of all spaces in the Gallery was undertaken. This survey was complemented by a special statistical analysis of U.S Art Gallery and Museum Fires[8] commissioned by the authors and undertaken by the NFPA.

From this work came important information on

\author{
rate of fire starts \\ first item ignited \\ fire causes \\ typical fire spread
}

which enabled the design fires or maximum fire growth rates to be decided upon as input to fire models for the study. 
The onset of hazardous conditions in egress paths was, for the purposes of this study, taken to be the point of flashover in any of the smaller offices and work rooms. The analysis made use of the FIREFORM fire engineering tools developed by Nelson[9] such as

\author{
Thomas flashover correlation \\ Kawagoe equation for burning rate at ventilation control \\ DETACT calculation of detector/sprinkler operating time \\ ASET and other fire growth models
}

For the Evacuation Duration Required ED (REQ), the computer model EVACNET+ developed by Kisko[2] was used. Like many models, there was concern over its utility and validity. Accordingly, it was agreed with NGV management that a full evacuation of the Gallery would be conducted to validate the model. The EVACNET+ program was then used to model evacuation for the maximum population expected.

\title{
EVACUATION RESULTS
}

The evacuation took a total of 480 seconds and produced some most interesting results that have very significant bearing on design of egress for people from public buildings. There are 2 main entrance/exit areas for the public entering and leaving the Gallery. These are known as :-

Main St. Kilda Road entrance/exit where there are 2 separate double leaf doors, one set for entrance and one for exit.

The so called north entry/exit when two simple leaf doors and a single rotating door are provided.

There are three four hour rated, concrete encased exit stairs situated around the Gallery that are marked with 'EXIT' signs that discharge to the outside. There are also other nonfire rated egress paths, namely

open stairs between floors.

open escalators in the main foyer.

an open circular stair surrounding an elevator (lift) between floors.

Table 1 shows the results of the evacuation in terms of the evacuation times from the "red alert" and populations that discharged from the various exits. 


\begin{tabular}{|c|c|c|c|}
\hline $\begin{array}{c}\text { Exit } \\
\text { Designator }\end{array}$ & $\begin{array}{l}\text { Exit Name/ } \\
\text { Location }\end{array}$ & $\begin{array}{l}\text { Population } \\
\text { Discharged }\end{array}$ & $\begin{array}{l}\text { Evacuation } \\
\text { Time }(\mathrm{sec})\end{array}$ \\
\hline A & $\begin{array}{l}\text { North Exit } \\
\text { (Leaf Door) }\end{array}$ & 37 & 420 \\
\hline B & $\begin{array}{l}\text { North Exit } \\
\text { (Rotating Door) }\end{array}$ & 238 & 420 \\
\hline $\mathrm{C}$ & $\begin{array}{l}\text { Main Exit } \\
\text { (St Kilda Road) }\end{array}$ & 341 & 480 \\
\hline $\mathrm{D}$ & $\begin{array}{l}\text { Main Entrance } \\
\text { (St Kilda Road) }\end{array}$ & 398 & 480 \\
\hline $\mathrm{E}$ & $\begin{array}{l}\text { St. Kilda Road F.R. } \\
\text { Staircase (single } \\
\text { leaf) }\end{array}$ & 0 & - \\
\hline F & $\begin{array}{l}\text { F.R. Staircase exit } \\
\text { at restaurant }\end{array}$ & 0 & - \\
\hline \multirow[t]{2}{*}{ G } & $\begin{array}{l}\text { F.R. Staircase exit } \\
\text { to Cafe }\end{array}$ & 0 & - \\
\hline & TOTAL & 1014 & 480 \\
\hline
\end{tabular}

Table 1 Exit discharge populations and evacuation times during actual NGV evacuation.

The most striking feature of this exercise was that nobody made their evacuation through the purpose built, fire rated exit stairs that would give the best protection in the event of fire. The whole population exited via unprotected routes that were probably the ones by which they entered the building and which were familiar to the public. This is entirely consistent with previous research reported by Sime[10] and Pauls[11]. Routes that are not regularly used by occupants will not be used by people making 'rational' decisions about escape.

The implication for building designers and regulators is that fire rated exit stairs must be made part of the normal building circulation pattern or else they are potentially a complete waste of valuable fire safety expenditure. In addition, both the alarm warning system and the advice provided by staff to the public must be to direct occupants to use the fire rated staircases for most efficient evacuation

Another key observation was that staff and the public, given to understand there was a fire, evacuated the building in a completely orderly manner, with staff assisting and directing the public. 
This again is entirely consistent with other research cited by Sime[12] that suggests that people do not 'panic' in emergencies but exhibit totally rational behaviour.

Three other pieces of data came from this evacuation study that aligns with literature values.

(i) The average travel speed of occupants on the Gallery floors, as a result of a large number of observations, was $1.0 \mathrm{~m} / \mathrm{s}$. This is consistent with maximum (unimpeded) exit floor speeds of $1.19 \mathrm{~m} / \mathrm{s}$ and a speed of $1.0 \mathrm{~m} / \mathrm{s}$ when the density is 1.1 persons $/ \mathrm{m}^{2}$ that are documented by Nelson and Maclennan[13].

(ii) A total of 238 people evacuated through the North rotating exit in 420 seconds. This equates to 0.57 persons/sec that is consistent with 0.5 persons $/ \mathrm{sec}$ suggested by Pauls[11] as a good design figure.

(iii) At the St. Kilda Road entrance that was used as an exit during the evacuation, 398 people left through 2 door $(.910 \mathrm{~mm})$ leafs in 480 seconds ie. 0.41 person/sec. This is considerably less than the 1 person/sec per door leaf suggested by Pauls[11] for moderate to optimum flow conditions. However, reasons such as crowding at the nearby cloak room, the congestion outside the door and the few people who tried to re-enter against the flow were probably responsible for the low observational figure.

\section{COMPUTER PREDICTIONS}

\section{Evacnet+}

To model the duration required for occupants to evacuate the building, evacuation studies were conducted using the computer program EVACNET+[2].

The EVACNET+ network uses the equations for people movement based on work carried out by Pauls[3] and Fruin[14]. Therefore it was also decided to do some egress time calculations using Pauls' formulas in order to check the results obtained from the computer model.

\section{Input to the Computer Model}

The EVACNET+ program requires a network description of a building and information about the initial distribution of occupants at the beginning of the evacuation. The network model consists of a set of nodes (rooms, galleries, foyers, halls, staircases, etc.) and arcs which represent the passageways between these nodes. 


\section{Node Input}

Two types of input data were required for the nodes:

* the node capacity

* the initial contents of the node

For the model of the National Gallery the node capacities were calculated using an approximate net free floor area for each node. Then an average floor density level which allowed for "standing and free circulation through the area without disturbing the others" [14] was selected.

For the Gallery evacuation exercise, input including the initial population was based on the data collected during the survey.

\section{Arc Input}

Three types of input data were required for the arcs:

* level of service and average flow volumes,

* effective width of the arc (door, staircase, hall, room etc.),

* travel speeds on floors and staircases and the traversal times.

The level of service concept can be defined as "maximum number of people to pass a fixed point in a given amount of time per unit effective arc width"[11].

A level of service with the following description was used:

"normal walking speeds only occasionally restricted; some occasional interference in passing; crossing and reverse movements are possible with occasional conflict; flow is approximately $35 \%$ of the maximum capacity".[14]

The travel speeds on floors and staircases were estimated with respect to the level of service assumed ie. related to the occupant density. As a result the speed in corridors was taken as $0.85 \mathrm{~m} / \mathrm{sec}$ and the time between landings as $12.0 \mathrm{sec}$, slightly more conservative than found during the actual evacuation.

\section{Other Inputs}

If no actual evacuation had been conducted then the EVACNET+ model would have probably been run with :-

uniform use of all staircases and exits.

people flow only in one direction (towards the outside of the Gallery). 
However, the flexibility of the EVACNET+ model and its interactive data input capability allowed modifications to be easily made for factors observed in the actual evacuation. Some examples are:-

(a) During the evacuation only the entrance and exit doors on St. Kilda Road and the doors on north side of the building were used. None of the fire rated staircases and other exits on south west side of the building were utilised.

Modification: The connections from the gallery to outside via unused staircases and exits were disconnected.

(b) It was observed from video recordings of the evacuation that some people had moved back inside from the main entrance door on St. Kilda Road to get their belongings from the cloakroom.

Modification: The number of people going back in was deducted from the total number of people using this exit.

(c) On the North side of the building only a few people used one of the two single leaf doors, and the rest used the rotating doors. The other single leaf door was not used at all.

Modification: The total door width was divided into two separate parts, one representing the single-leaf door and the other representing the rotating door. By working back from the numbers using each of these exits, effective door widths and dynamic capacities were calculated.

\section{Pauls' Model}

The egress model developed by Pauls[3] is also known as the effective-width model for the crowd movement. This empirically based model describes flow as a linear function of a walkway's/stair's effective width.

The effective-width model takes into account the propensity of people to arrange themselves in staggered configuration. The effective width approach also assumes that mean evacuation flow varies in non-linear fashion with evacuation population. Other factors, besides effective stair width, influencing the mean flow in evàcuations are various building design and use factors.

Pauls' model uses time based egress calculations to work out crowd density, speed and flow. In doing that they utilise a crowd movement parameters table (based on various facilities and conditions). Pauls' model was used to hand calculate evacuation times.

\section{COMPARISON OF ACTUAL AND ESTIMATED EGRESS TIMES}

The results of the model predictions of egress times for a population of 1014 people compared with the actual times recorded in the evacuation were in excellent agreement as shown in Table 2 . 


\begin{tabular}{|c|l|c|c|c|}
\hline $\begin{array}{c}\text { Exit } \\
\text { Designator }\end{array}$ & \multicolumn{1}{|c|}{$\begin{array}{c}\text { Exit Name/ } \\
\text { Location }\end{array}$} & $\begin{array}{c}\text { Actual } \\
\text { Evacuation } \\
\text { Time }(\mathrm{sec})\end{array}$ & $\begin{array}{c}\text { EVACNET+ } \\
\text { Prediction } \\
(\mathrm{sec})\end{array}$ & $\begin{array}{c}\text { Paul's } \\
\text { Model } \\
\text { Prediction } \\
\text { (sec) }\end{array}$ \\
\hline $\mathrm{A}$ & $\begin{array}{l}\text { North exit } \\
\text { (Leaf Door) }\end{array}$ & 420 & 424 & N/A \\
\hline B & $\begin{array}{l}\text { North exit } \\
\text { (Rotating door) }\end{array}$ & 420 & 424 & 364 \\
\hline C & $\begin{array}{l}\text { Main exit } \\
\text { (St. Kilda Rd) }\end{array}$ & 480 & 521 & 520 \\
\hline D & $\begin{array}{l}\text { Main entrance } \\
\text { (St. Kilda Rd) }\end{array}$ & 480 & 512 & 470 \\
\hline
\end{tabular}

TABLE 2: Actual and Predicted Evacuation Times

This level of agreement between theory and practice gave confidence in the use of the EVACNET+ model and model calculations were repeated for :-

(a) a maximum population expected of 3260 based on NGV data for major exhibitions.

(b) scenarios in which one or more of the evacuation paths was cut off by a potential fire.

(c) scenarios in which all exits, including enclosed stairways, were used reasonably equally (that might result from better Gallery attendant training and improved evacuation information to the public.)

Again, the calculations were made relatively straightforward by the interactive flexibility of the EVACNET+ model. For example, the calculations showed that for the design population of 3260 , the evacuation time could be cut from 1088 seconds to 736 seconds if all exits, including fire rated stairways, were used equally.

\section{FINAL FIRE SAFETY PACKAGE}

The egress calculations for a maximum population of 3260 showed evacuation would not be completed before flashover and the potential existed for occupants to be trapped in egress routes by toxic smoke.

The engineering analysis suggested the following key fire safety measures :-

(a) The building should be fully sprinklered to prevent flashover, protect people and prevent significant damage to the building and its contents. 
(b) Smoke detectors and an emergency warning and intercommunication system (EWIS) should be installed to reduce the 'time to move' that Sime[10] has identified as critical to life safety.

(c) Smoke barriers around open stairs in the form of tempered glass partitions with doors on magnetic hold open/release mechanisms should be installed to prevent smoke entry into normal circulation egress paths.

(d) Staff training should be provided to reduce evacuation times.

All these measures are currently being installed in the National Gallery of Victoria as a result of this major study[6].

\section{CONCLUSIONS}

Fire research has provided engineers with practical tools that can be used to undertake a performance based fire engineering analysis as demonstrated in this study in the National Gallery of Victoria.

An actual full evacuation of the Gallery provided data on egress times that compared well with predictions using the EVACNET+ computer software (under defined conditions) and Paul's model.

The evacuation showed that fire rated stairways that were not part of the normal building circulation pattern were not used for evacuation people will exit via familiar paths, usually the way they entered.

Experimental data and observations of human behaviour were consistent with other research relating to travel speeds.

The evacuation highlighted the need for advisory warning messages and staff training.

\section{REFERENCES}

1. Cooper, L.Y. "A Mathematical Model for Estimating Available Safe Egress Time in Fires", Fire and Materials, 6, pp 135-144 1982.

2. Kisko, T.M., "EVACNET+", Department of Industrial and Systems Engineering, University of Florida, 1984

3. Pauls, J.L. "Effective-Width Model for Evacuation Flow in Buildings", in Proceedings, Engineering Applications Workshop, Society of Fire Protection Engineers, Boston 1980.

4. National Fire Protection Association, "Recommended Practice for the Protection of Museum Collections", NFPA 911, Quincy, USA, 1980. 
5. Morris, J., "Protecting the Library from Fire - a US Viewpoint with Lessons from other Countries", Fire Prevention, No. 192, London, pp 26-29, 1986.

6. Beck, V.R., Johnson P.F. \& Lacey, R.H. "Fire Safety and Protection Strategy for the National Gallery of Victoria", 1990.

7. Quaglia, C., "Deterministic Fire Safety Engineering", Paper to BCA Equivalence Acceptance of Alternative Fire Protection Design in Buildings, AFPA/CSIRO Seminar, Sydney, 1992.

8. Miller, A.L., "US Art Gallery and Museum Fires 1983-1987 - Special Analysis", National Fire Protection Association, 1980.

9. Nelson, H.E., "Fireform - A Computerized Collection of Convenient Fire Safety Computations", NBSIR86 - 3308, National Bureau of Standards, Gaithersburg, USA, 1986.

10. Sime, J.D. "Movement toward the familiar; person and place affiliation in a fire entrapment Setting", Environment and Behaviour, 17:6, pp 697-724, 1985.

11. Pauls, J., "Movement of People", Section 1 Chapter 15, The SFPE Handbook of Fire Protection Engineering, 1st Edition, SFPE/NFPA, 1988.

12. Sime, J.D., "The Concept of Panic", Fires and Human Behaviour, ed D. Canter, pp 63-81, First Edition, Wiley, London, 1980.

13. Nelson, H.E. \& MacLennan, H.A., "Emergency Movement", Section 2, Chapter 6, The SFPE Handbook of Fire Protection Engineering, 1st Edition, SFPE/NFPA, 1988.

14. Fruin, J.J., "Pedestrian Planning and Design, MAUDEP Inc, 1971.

15. Proulx, G and Sime J.D, "To Prevent 'Panic' in an Underground Emergency: Why Not Tell People the Truth", Fire Safety Science - Proceedings of the Third International Symposium, Eds.G.Cox, B.Langford, Elsevier Applied Science, 1991. 